\title{
Hubungan Pengetahuan dan Sikap Keluarga dengan Tingkat Kecacatan pada Penderita Kusta di Kabupaten Padang Pariaman Tahun 2013
}

Agusti Nala Sari ${ }^{1}$, Rina Gustia², Edison ${ }^{3}$

\begin{abstract}
Abstrak
Keluarga sebagai sistem pendukung bagi penderita kusta diharapkan mampu memberikan dukungan penuh dalam upaya penurunan tingkat kecacatan penderita kusta dengan pengetahuan yang baik dan sikap yang positif terhadap penyakit kusta. Hal ini terkait dengan jumlah penderita kusta di Kabupaten Padang Pariaman merupakan yang tertinggi di wilayah Sumatera Barat. Tujuan penelitian ini adalah untuk menentukan hubungan pengetahuan dan sikap keluarga dengan tingkat kecacatan penderita kusta di Kabupaten Padang Pariaman tahun 2013. Penelitian dilaksanakan di wilayah kerja Puskesmas Pauh Kambar dan UlakanKabupaten Padang Pariaman dengan desain cross sectional. Jumlah subjek 32 orang dengan teknik total sampling. Pengumpulan data dilakukan melalui wawancara dengan menggunakan kuesioner dan analisis data menggunakan uji chi-square.Hasil penelitian ini menunjukkan bahwa kedua variabel yang diteliti, yakni pengetahuan ( $p=0,023$ OR=11,0 dan 95\% Cl 1,19-101,98) dan sikap ( $p=0,035 \mathrm{OR}=7,2$ dan $95 \% \mathrm{Cl}$ 1,31-39,56) keluarga dengan tingkat kecacatan penderita kusta di Kabupaten Padang Pariaman. Berdasarkan penelitian ini dapat disimpulkan bahwa terdapat hubungan yang bermakna antara pengetahuan dan sikap keluarga dengan tingkat kecacatan penderita kusta di Kabupaten Padang Pariaman.
\end{abstract}

Kata kunci: pengetahuan, sikap, tingkat kecacatan, kusta

\begin{abstract}
Family is a support system for people with leprosy that are expected to provide full support in an effort to decrease the defect rate of leprosy patients with good knowledge and positive attitudes about leprosy. It is related to the number of leprosy patients in the regency of Padang Pariaman is the highest in West Sumatra. The objective of this study was to determine correlation between knowledge and attitudes of families with the grading of disabilities in leprosy patients in the regency of Padang Pariaman 2013. The experiment was conducted at Puskesmas Pauh Kambar and Puskesmas Ulakan in the regency of Padang Pariaman by using a cross-sectional design. The number of subjects were 32 people with a total sampling techniques. Data collected through interviews using questionnaires and data analysis using chi-square test. The results of this study indicate that both variables studied, knowledge $(p=0.023$ and $O R=11.0$, and $95 \% \mathrm{Cl} 1.19$ to 101.98) and attitude ( $p=0.035 \mathrm{OR}=7.2$, and 95\% Cl 10.31 to 39.56) families with the level of disability of patients with leprosy in the regency of Padang Pariaman. Based on this study it can be concluded that there is a significant relationship between knowledge and attitudes of families with the level of disability of patients with leprosy in the regency of Padang Pariaman.
\end{abstract}

Keywords: knowledge, attitudes, disability grading in leprosy

Affiliasi penulis: 1. Pendidikan Dokter FK UNAND (Fakultas Kedokteran Universitas Andalas Padang), 2. Bagian IImu Kesehatan Kulit dan Kelamin FK UNAND/RS Dr. M. Djamil, 3. Bagian IImu Kesehatan Masyarakat FK UNAND

Nama Penulis: Agusti Nala Sari, E-mail: nala.satya09@gmail.com, Telp: 085274389333

\section{PENDAHULUAN}

Penyakit kusta merupakan penyakit kronis yang menyerang saraf tepi, kulit dan jaringan tubuh lainnya. Diagnosis penyakit kusta ditegakkan dengan ditemukannya tanda utama, yaitu: adanya lesi kulit yang mati rasa, penebalan saraf tepi dengan disertai 
gangguan fungsi saraf serta ditemukannya Bakteri Tahan Asam (BTA). ${ }^{1}$

Pada tahun 2006, The International Federations of Anti Leprosy Associations (ILEP) dan WHO mengeluarkan strategi global untuk menurunkan beban penyakit dan kesinambungan program pemberantasan penyakit kusta (2006 - 2010). Sejak pertengahan tahun 2006 strategi tersebut dipakai dalam kebijakan pemberantasan penyakit kusta di Indonesia. ${ }^{2}$ Tahun 2012, jumlah kasus baru yang tercatat 18.994 (PR 0.78/10.000) dimana Indonesia merupakan peringkat ketiga tertinggi dunia. ${ }^{3}$

Pada kurun waktu 2001-2011 terjadi kecenderungan peningkatan proporsi cacat tingkat 2 . Kecenderungan peningkatan proporsi pada anak nampak dari tahun 2005-2011. ${ }^{4}$ Indonesia melaporkan untuk tahun 2012 proporsi cacat tingkat 2 sebesar 2131 kasus dari total 18.994 kasus baru yang terdeteksi. ${ }^{3}$ Dari 33 propinsi di Indonesia, Sumatera Barat merupakan salah satu dari 14 propinsi yang belum mencapai target eliminasi kusta. Sumatera Barat sendiri memiliki tingkat cacat yang tinggi untuk cacat tingkat 2 menurut laporan tahunan P2 kusta Propinsi Sumatera Barat. ${ }^{5}$

Penemuan penderita tahun 2011 di Kabupaten Padang Pariaman bila dibandingkan dengan kabupaten/kota yang ada di Propinsi Sumatera Barat secara absolut jumlahnya merupakan urutan pertama terbanyak, jumlah penderita cacat 46 orang dengan PR 43,80\%, dan jumlah tidak cacat 69 orang dengan PR 65,71\%.Dilaporkan dari tahun 2009 - 2012 jumlah penderita kusta yang terdaftar adalah sebanyak 105 orang dengan PR 0.0264/10.000 penduduk. Dari 23 puskesmas, puskesmas dengan jumlah penderita kusta tertinggi berada di wilayah Pauh Kambar 21 kasus, Ulakan 13 kasus, Sintuak dan Pakandangan masing-masing 9 kasus, sisanya berada di wilayah lainnya. ${ }^{6}$

Pemahaman/pengetahuan yang kurang dari anggota keluarga terhadap penderita kusta karena ketakutan akan kemungkinan penularan penyakit tersebut akan mempengaruhi partisipasi anggota keluarga dalam hal perawatan kesehatan anggota keluarga yang menderita kusta sehingga keluarga kurang memberikan dukungan kepada penderita untuk memanfaatkan fasilitas pelayanan kesehatan dalam mengobati penyakitnya tersebut. ${ }^{7}$ Apabila pengetahuan individu terhadap suatu penyakit tidak atau belum diketahui, maka sikap dan tindakan dalam upaya pencegahan penyakit pun terkadang terabaikan. ${ }^{8}$

Berdasarkan penelitian Susanto di Kabupaten Sukoharjo didapatkan bahwa pengetahuan mempunyai hubungan yang signifikan dengan tingkat kecacatan. ${ }^{9}$ Penelitian di Rumah Sakit dr. Tadjuddin Chalid Makassar, menjelaskan ada hubungan yang bermakna antara pengetahuan dan sikap dengan upaya pencegahan kecacatan penyakit kusta. ${ }^{10} \mathrm{Hal}$ ini yang membuat perlu diteliti hal serupa di Kabupaten Padang Pariaman dengan mengambil 2 puskesmas tertinggi untuk kasus kusta. Penelitian ini bertujuan untuk mengetahui hubungan pengetahuan dan sikap keluarga dengan tingkat kecacatan pada penderita kusta di Kabupaten Padang Pariaman.

\section{METODE}

Desain penelitian yang digunakan adalah analitik korelasi dengan pendekatan cross sectional. Metode analitik korelasi pada penelitian ini digunakan untuk mengukur hubungan pengetahuan dan sikap keluarga dengan tingkat kecacatan pada penderita kusta.

Populasi dalam penelitian ini yaitu keluarga dari penderita kusta yang dipilih dari 2 puskesmas di Kabupaten Padang Pariaman dengan penderita kusta terbanyak, yaitu Puskesmas Pauh Kambar dan Ulakan dengan jumlah total 34 orang. Dengan rincian Puskesmas Pauh Kambar 21 orang dan Puskesmas Ulakan 13 orang.

Instrument dalam penelitian ini adalah kuesioner untuk wawancara dengan keluarga penderita dan laporan pencacatan dari puskesmas untuk mengetahui tingkat kecacatan penderita kusta. Penelitian ini dilaksanakan pada bulan Februari 2014.

Analisis univariat dilakukan terhadap setiap variabel yang akan menghasilkan distribusi dan persentasi setiap variablel dan analisa bivariat dilakukan untuk melihat hubungan antara variabel independen dan variabel dependen. Hubungan kedua variabel tersebut dilakuan uji chi square yang apabila $\mathrm{p}<0,05$ berarti terdapat hubungan antara variabel independen dan variabel dependen 


\section{HASIL DAN PEMBAHASAN}

Penelitian ini dilakukan di wilayah kerja Puskesas Pauh Kambar dan Puskesmas Ulakan dengan 32 responden dari total 34 responden, dengan hasil sebagai berikut.

\section{Karakteristik Responden}

Dibawah ini diuraikan distribusi responden berdasarkan data demografi keluarga penderita kusta yang berobat di Puskesmas Pauh Kambar dan Puskesmas Ulakan dari tahun 2009-2013.

Tabel 1. Karakteristik responden menurut jenis kelamin, umur, tingkat pendidikan, jenis pekerjaan dan hubungan keluarga

\begin{tabular}{|c|c|c|c|}
\hline No. & $\begin{array}{l}\text { Karakteristik } \\
\text { Responden }\end{array}$ & Frekuensi & $\begin{array}{l}\text { Presentase } \\
\text { (\%) }\end{array}$ \\
\hline 1. & $\begin{array}{l}\text { Jenis Kelamin } \\
\text { Laki-laki } \\
\text { Perempuan } \\
\text { Jumlah }\end{array}$ & $\begin{array}{r}8 \\
24 \\
32\end{array}$ & $\begin{array}{c}25,0 \\
75,0 \\
100,0\end{array}$ \\
\hline 2. & $\begin{array}{l}\text { Umur } \\
20-40 \text { tahun } \\
41-60 \text { tahun } \\
\geq 61 \text { tahun } \\
\text { Jumlah }\end{array}$ & $\begin{array}{r}16 \\
13 \\
3 \\
32\end{array}$ & $\begin{array}{r}50,0 \\
40,6 \\
9,4 \\
100,0\end{array}$ \\
\hline 3. & $\begin{array}{l}\text { Tingkat Pendidikan } \\
\leq \mathrm{SD} \\
\text { Tamat SMP } \\
\text { Tamat SMA } \\
\text { Tamat PT } \\
\text { Jumlah }\end{array}$ & $\begin{array}{r}14 \\
7 \\
8 \\
3 \\
32\end{array}$ & $\begin{array}{r}43,7 \\
21,9 \\
25,0 \\
9,4 \\
100,0\end{array}$ \\
\hline 4. & $\begin{array}{l}\text { Jenis Pekerjaan } \\
\text { lbu rumah tangga } \\
\text { Petani } \\
\text { Buruh } \\
\text { PNS } \\
\text { Tidak bekerja } \\
\text { Jumlah }\end{array}$ & $\begin{array}{r}19 \\
6 \\
2 \\
1 \\
4 \\
32\end{array}$ & $\begin{array}{r}59,4 \\
18,8 \\
6,2 \\
3,1 \\
12,5 \\
100,0\end{array}$ \\
\hline 5. & $\begin{array}{l}\text { Hubungan Keluarga } \\
\text { Ayah/ibu } \\
\text { Anak } \\
\text { Kakak/adik } \\
\text { Suami/istri } \\
\text { Lain-lain } \\
\text { Jumlah }\end{array}$ & $\begin{array}{r}12 \\
7 \\
4 \\
8 \\
1 \\
32\end{array}$ & $\begin{array}{r}37,5 \\
21,9 \\
12,5 \\
25,0 \\
3,1 \\
100,0\end{array}$ \\
\hline
\end{tabular}

Ddistribusi responden menurut jenis kelamin, terlihat bahwa mayoritas responden adalah perempuan sebanyak 24 orang $(75,0 \%)$. Selain perempuan, dijumpai beberapa responden pula yang berjenis kelamin laki-laki sebanyak 8 orang (25,0\%) yang masih dapat menjelaskan fungsinya dalam memberikan perawatan kepada anggota keluarganya yang menderita kusta. Pengalaman merawat merupakan suatu bentuk dari sikap individu yang berhubungan dengan peran di dalam keluarga. ${ }^{11}$ Dapat disimpulkan tanpa membedakan laki-laki maupun perempuan, seorang keluarga dapat menunjukkan kemampuan yang baik dalam hal merawat penderita kusta dan memberikan dukungan psikologis maupun sosial.

Mayoritas rentang usia keluarga penderita kusta adalah antara 20-40 tahun. Kemampuan kognitif dan kemampuan perilaku sangat dipengaruhi oleh tahap perkembangan usia seseorang. ${ }^{12}$

Sebagian besar responden tidak tamat sekolah dasar (SD) atau hanya sampaitamat SD sebanyak 14 orang (43,7\%). Menurut Susanto pendidikan yang rendah merupakan salah satu faktor kurangnya tindakan pencarian pengobatan bagi penderita kusta sehingga pengobatan dilakukan jika penyakit yang diderita sudah parah. $^{9}$ Pendidikan yang rendah mengakibatkan kurangnya pengetahuan terhadap penyakit kusta, sehingga keluarga penderita kusta tidak memahami akibat buruk yang ditimbulkan dari penyakit kusta.

Jenis pekerjaan sebagian besar responden adalah ibu rumah tangga sebanyak 19 orang $(59,4 \%)$, dimana sebagian besar waktu responden berada dirumah dan dapat membantu dalam perawatan penderita kusta. Hal ini sesuai dengan peran keluarga sebagai caregiver yang mana menurut penelitian Donelan et al, sebanyak $20 \%$ caregiver memberikan waktunya 40 jam atau lebih perminggu dalam merawat keluarganya yang sakit. ${ }^{13}$ Dapat disimpulkan keluarga dengan waktu dirumah yang lebih banyak dapat merawat pasien secara lebih efektif.

Mayoritas responden adalah keluarga inti, meliputi suami, istri, anak, ibu, atau ayah sebanyak 31 orang dan sisanya 1 orang keluarga diluar inti adalah keponakan dari penderita. Family support system (sistem dukungan keluarga) merupakan suatu sistem pendukung yang diberikan oleh keluarga terhadap anggota keluarga dalam rangka mempertahankan identitas sosial anggota keluarga, memberikan dukungan emosional, bantuan materil, memberikan informasi dan pelayanan, dan memfasilitasi anggota keluarga dalam membuat kontak sosial baru dengan masyarakat. Keluarga sebagai sistem pendukung 
bagi penderita kusta diharapkan mampu memberikan dukungan penuh dalam upaya perawatan penderita kusta. Terlebih dengan kondisi penyakit kusta dan masalah psikososial yang bisa muncul akibat penyakit kusta, diantaranya: masalah terhadap diri penderita kusta, masalah terhadap keluarga penderita kusta, dan masalah terhadap masyarakat sekitar penderita kusta. Tanpa harus membedakan keluarga inti maupun non inti, seorang keluarga harus mampu dalam merawat keluarganya yang sakit. ${ }^{14}$

\section{Pengetahuan Responden}

Berdasarkan hasil penelitian didapatkan distribusi frekuensi pengetahuan responden tentang penyakit kusta sebagai berikut:

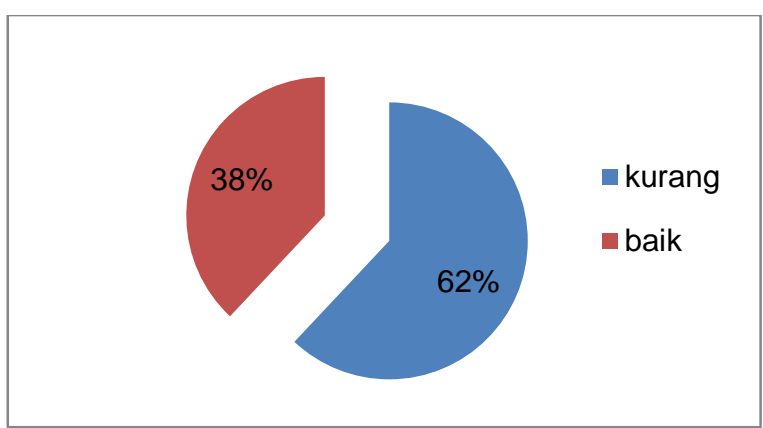

Gambar 1. Distribusi frekuensi pengetahuan tentang penyakit kusta

Hasil univariat menyebutkan responden berpengetahuan kurang sebanyak 20 orang (62\%) dan yang berpengetahuan baik sebanyak 12 orang (38\%). Hal ini menunjukkan masih banyak responden yang belum mengetahui pengertian, penyebab, tandatanda, cara penularan, pengobatan, pencegahan kecacatan penyakit kusta. Penelitian ini didukung dengan penelitian Susanto di Kabupaten Sukoharjo yang menyatakan sebagian besar responden berpengetahuan sedang $(41,3 \%){ }^{9}$

Pengetahuan merupakan hasil "tahu" dan ha ini terjadi setelah sebelumnya melakukan pengindraan terhadap suatu objek tertentu. ${ }^{15}$ Pengetahuan tentang kesehatan dan perilaku pencarian pengobatan memiliki hubungan terhadap munculnya kecacatan pada penderita kusta. Menurut pengamatan peneliti salah satu faktor penyebab kurangnya pengetahuan keluarga adalah masih banyak responden yang berpendidikan rendah dan penerimaan hasil penyuluhan dari petugas puskesmas yang kurang baik oleh responden dan masih menganggap kusta merupakan penyakit yang memalukan. Oleh sebab itu masih perlu di sampaikan informasi lebih dalam dan merata kepada semua responden mengenai penyakit kusta dan komplikasinya yang berupa kecacatan apabila tidak diobati segera.

\section{Sikap Responden}

Berdasarkan hasil penelitian di dapatkan distribusi frekuensi sikap responden terhadap penyakit kusta sebagai berikut:

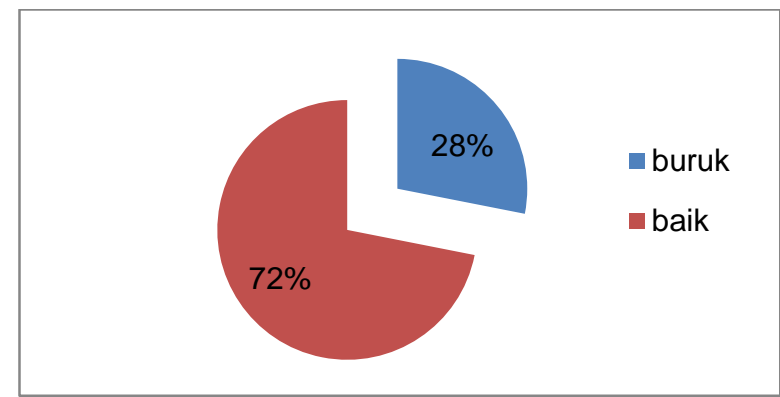

Gambar 2. Distribusi frekuensi sikap terhadap penyakit kusta

Hasil univariat menyebutkan sebagian besar responden mempunyai sikap yang baik terhadap penyakit kusta yaitu sebanyak 23 orang (72\%) orang dan sebagian kecil mempunyai sikap yang buruk sebanyak 9 orang (28\%) orang dari total 32 responden. Hal ini didukung oleh penelitian Rahayu yang menyatakan dukungan psikososial keluarga penderita kusta meliputi dukungan psikologis yang berada dalam kategori baik (73,8\%). ${ }^{7}$ Penelitian Mongi di Kota Manado yang menunjukkan dukungan keluarga yang diberikan kepada penderita meliputi dukungan emosional adalah baik yaitu $76.2 \%$, dukungan instrumental adalah baik yaitu $81 \%$ dan dukungan informasi juga sudah baik yaitu $83.3 \% .^{16}$

Sikap merupakan salah satu predisposisi tindakan yang dapat menggambarkan ketertarikan maupun ketidaktertarikan seseorang terhadap stimulus, tetapi belum suatu tindakan atau perilaku. Harju et al menyatakan bahwa sikap dapat memainkan peran kunci bagi seseorang dalam memutuskan kapan dan dimana untuk mencari perawatan medis. ${ }^{17}$ Dengan demikian untuk mendapatkan sikap yang benar terhadap pencarian pengobatan kusta, penderita kusta, keluarga maupun masyarakat perlu diberikan informasi atau penyuluhan secara rutin tentang pengobatan kusta yang tepat. 
Peningkatan pemahaman penderita kusta maupun masyarakat tentang penyakit kusta serta pengobatan yang tepat akan mewujudkan sikap yang baik terhadap penyakit tersebut dan akan terbentuk perilaku yang tepat pula dalam melakukan pengobatan kusta secara tepat.

\section{Tingkat Kecacatan Penderita Kusta}

Berdasarkan hasil penelitian di dapatkan distribusi frekuensi tingkat kecacatan penderita penyakit kusta sebagai berikut:

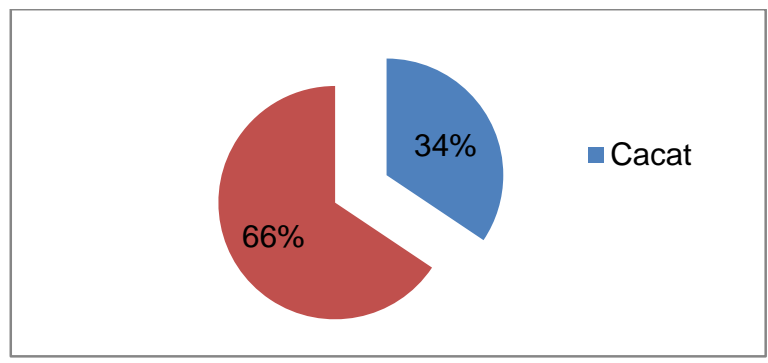

Gambar 3. Distribusi frekuensi tingkat kecacatan penderita kusta

Hasil univariat menyebutkan sebagian besar penderita kusta tidak cacat atau memiliki kecacatan tingkat 0 sebanyak 21 orang (66\%), kemudian cacat sebanyak 11 orang (34\%) yaitu kecacatan tingkat 1 sebanyak 6 orang (19\%) dan kecacatan tingkat 2 sebanyak 5 orang (15\%) dari total 32 responden.

Penelitian ini bertentangan dengan penelitian Susanto yang menyatakan keadaan tingkat kecacatan di Kabupaten Sukoharjo sebagian besar adalah cacat $(92,7 \%) .^{9}$ Hasil ini berbeda karena cakupan penelitian yang luas yaitu satu kabupaten dan Susanto sendiri menyatakan kurangnya pengetahuan petugas pemegang program kusta dalam mengklasifikasikan tipe kusta sehingga terdapat sebagian penderita yang salah dalam klasifikasi jenis kusta. ${ }^{9}$ Penelitian ini hanya meneliti 2 puskesmas di Kabupaten Padang Pariaman dengan persentase penderita kusta terbanyak dan menurut data dari laporan Dinas Kesehatan Kabupaten Padang Pariaman yang menyebutkan mayoritas penderita di Kabupaten Padang Pariaman mengalami tingkat kecacatan 0 atau tidak cacat dengan PR 65,71\%. Dapat disimpulkan program pemberantasan penyakit kusta dari Dinas Kesehatan Kabupaten Padang Pariaman di wilayah kerja Puskesmas Pauh Kambar dan Puskesmas Ulakan cukup berhasil.

\section{Hubungan Pengetahuan dengan Tingkat Kecacatan pada Penderita Kusta}

Berdasarkan hasil penelitian maka didapat hubungan pengetahuan keluarga dengan tingkat kecacatan penderita kusta adalah sebagai berikut:

Tabel 2. Hubungan pengetahuan dengan tingkat kecacatan

\begin{tabular}{|c|c|c|c|c|c|c|c|c|}
\hline \multirow{3}{*}{$\begin{array}{l}\text { Penge- } \\
\text { tahuan }\end{array}$} & \multicolumn{4}{|c|}{ Tingkat Kecacatan } & \multicolumn{2}{|c|}{ Total } & \multirow{3}{*}{ OR } & \multirow{3}{*}{$\mathbf{p}$} \\
\hline & \multicolumn{2}{|c|}{ Cacat } & \multicolumn{2}{|c|}{$\begin{array}{l}\text { Tidak } \\
\text { Cacat }\end{array}$} & \multirow[t]{2}{*}{ f } & \multirow[t]{2}{*}{$\%$} & & \\
\hline & $F$ & $\%$ & $f$ & $\%$ & & & & \\
\hline Baik & 1 & 8,3 & 11 & 91,7 & 12 & 100 & & \\
\hline Kurang & 10 & 50,0 & 10 & 50,0 & 20 & 100 & 11 & 0,02 \\
\hline Jumlah & 11 & 34,4 & 21 & 65,5 & 32 & 100 & & \\
\hline
\end{tabular}

Berdasarkan tabel diatas dapat dilihat hasil uji statistik, terdapat hubungan yang signifikan antara pengetahuan keluarga dengan tingkat kecacatan penderita kusta dengan nilai $p<0,05$ dan Odds Ratio (OR) 11,000 artinya keluarga dengan pengetahuan kurang lebih beresiko 11 kali lipat dalam kecacatan penderita kusta

Penelitian ini didukung oleh penelitian Antari yang menyatakan terdapat hubungan yang bermakna antara pengetahuan keluarga dengan upaya pencegahan kecacatan dalam kejadian kecacatan pada penderita kusta di Kabupaten Tegal dengan $p=$ 0,008 dan penelitian Permani yang menyatakan ada hubungan antara pengetahuan kontak serumah dengan kejadian kusta $(p<0,05) .{ }^{18,19}$

Tingkat pengetahuan yang cukup baik sangat dirasa berperan penting dalam penurunan angka kecacatan penderita kusta. Tingkat pengetahuan seseorang yang baik mengenai penyakit kusta tidak secara otomatis akan berbuat positif terhadap kecacatan penyakit tersebut, sebaliknya pengetahuan yang rendah atau kurang mengenai penyakit kusta belum tentu akan berbuat hal yang negatif. Bisa terlihat dari hasil penelitian bahwa ada 1 orang $(8,3 \%)$ responden yang berpengetahuan baik tapi keluarganya menderita cacat, hal ini disebabkan berbagai factor, salah satunya keterlambatan berobat dari penderita sendiri disamping keluarganya yang kurang kepedulian. Terdapat 10 orang (50\%) responden yang berpengetahuan kurang tapi keluarganya tidak cacat, hal ini juga disebabkan 
berbagai faktor, dari hasil pengamatan peneliti kebanyakan penderita yang cepat menyadari penyakitnya dan segera berobat.

Hasil penelitian ini sesuai dengan teori Green menyatakan bahwa adanya kecenderungan seseorang yang berpengetahuan tinggi akan lebih cenderung untuk berperilaku baik dalam bidang kesehatan dalam hal ini mencegah kecacatan keluarganya yang menderita penyakit kusta. ${ }^{20}$ Pendapat Bakker et al., yang mengatakan bahwa proporsi dari kasus baru dengan kecacatan tingkat 2 telah terjadi penurunan dengan diterapkannya penemuan kasus baru kusta, sehingga penegakan diagnosis kusta secara dini dapat mengurangi tingkat kecacatan kusta. ${ }^{21}$

Berdasarkan hasil penelitian dan pendapat yang telah dikemukakan, maka dapat dikatakan bahwa hasil penelitian ini sejalan dengan pendapat yang dikemukakan tersebut. Semakin tinggi pengetahuan keluarga tentang penyakit semakin baik pula tindakan yang dilakukan dalam merawat penderita kusta sehingga kecacatannya dapat dicegah dan diobati atau apabila telah terjadi cacat tingkat 1 agar tidak jatuh pada cacat tingkat 2 .

\section{Hubungan Sikap dengan Tingkat Kecacatan pada Penderita Kusta}

Berdasarkan hasil penelitian maka didapat hubungan sikap keluarga dengan tingkat kecacatan penderita kusta adalah sebagai berikut:

Tabel 3. Hubungan sikap dengan tingkat kecacatan

\begin{tabular}{|c|c|c|c|c|c|c|c|c|}
\hline \multirow{4}{*}{ Sikap } & \multicolumn{4}{|c|}{ Tingkat Kecacatan } & \multicolumn{2}{|c|}{ Total } & \multirow{4}{*}{ OR } & \multirow{4}{*}{ p } \\
\hline & \multirow{2}{*}{\multicolumn{2}{|c|}{ Cacat }} & \multicolumn{2}{|c|}{ Tidak } & \multirow{3}{*}{ f } & \multirow{3}{*}{$\%$} & & \\
\hline & & & \multicolumn{2}{|c|}{ Cacat } & & & & \\
\hline & $f$ & $\%$ & $f$ & $\%$ & & & & \\
\hline Baik & 5 & 21,7 & 18 & 78,3 & 23 & 100 & & \\
\hline Buruk & 6 & 66,7 & 3 & 33,3 & 9 & 100 & 7.2 & 0,035 \\
\hline Jumlah & 11 & 34,4 & 21 & 65,6 & 32 & 100 & & \\
\hline
\end{tabular}

Berdasarkan tabel diatas dapat dilihat terdapat hubungan yang signifikan antara sikap keluarga dengan tingkat kecacatan penderita kusta dengan nilai $\mathrm{p}<0,05$, Odds Ratio (OR) 7,200 artinya keluarga dengan sikap yang buruk lebih beresiko 7 kali lipat dalam kecacatan penderita kusta.

Hal ini membuktikan sikap yang cukup baik dari responden terhadap penderita kusta. Penelitian ini didukung oleh penelitian Antari yang menyatakan terdapat hubungan yang bermakna antara sikap keluarga dengan upaya pencegahan kecacatan dalam kejadian kecacatan pada penderita kusta di Kabupaten Tegal dengan $p=0,001 .{ }^{18}$ Penelitian Eliningsih yang menyatakan terdapat hubungan yang bermakna motivasi keluarga dengan kecacatan penderita kusta di Kabupaten Tegal dengan nilai $p=$ $0,005 .^{22}$

Sikap yang buruk belum tentu dapat membuat keluarganya yang menderita kusta mengalami kecacatan, terbukti ada 3 orang (33,3\%) responden dengan sikap yang buruk tapi keluarganya yang menderita kusta tidak mengalami kecacatan, hal ini disebabkan penderita kusta tersebut segera mengetahui penyakit yang ia derita dengan melihat tetangganya yang menderita penyakit yang sama sehingga penderita tersebut cepat memeriksakan penyakitnya ke puskesmas sedangkan keluarganya tidak begitu peduli dengan sakit yang dideritanya .

Banyak faktor yang dapat mempengaruhi sikap keluarga atau seorang individu seperti pengalaman pribadi, kebudayaan, orang lain yang dianggap penting, media massa, pendidikan dan lainnya. ${ }^{23}$ Faktor yang banyak mempengaruhi sikap keluarga adalah faktor kebudayaan dan pengalaman pribadi. Faktor kebudayaan contohnya masih ada persepsi yang salah tentang penyakit kusta dengan menganggap kusta sebagai penyakit guna-guna dan harus di jauhi. Faktor pengalaman pribadi keluarga biasanya lebih bersikap positif karena pernah mengalami kejadian serupa kemudian diberikan pengobatan dan mendapat penyuluhan, maka keluarga tersebut lebih bersikap positif dalam hal mendukung pengobatan kusta si penderita.

Dengan sikap yang baik atau positif, keluarga sebagai sistem pendukung bagi penderita kusta diharapkan mampu memberikan dukungan penuh dalam upaya perawatan penderita kusta. Terlebih dengan kondisi penyakit kusta dan masalah psikososial yang bisa muncul akibat penyakit kusta, diantaranya: masalah terhadap diri penderita kusta, masalah terhadap keluarga penderita kusta dan masalah terhadap masyarakat sekitar penderita kusta. ${ }^{24} \mathrm{Hal}$ ini tampak dari hasil penelitian bahwa $66 \%$ penderita kusta tidak mengalami kecacatan. 
Dari hasil penelitian dan pendapat yang dikemukakan, maka dapat dikatakan bahwa hasil penelitian ini sejalan dengan pendapat yang dikemukakan tersebut yaitu jika seorang keluarga memiliki sikap yang baik, maka dapat berpengaruh dalam menurunkan angka tingkat kecacatan penderita.

\section{KESIMPULAN}

Didapatkan tingkat kecacatan penderita kusta di wilayah kerja Puskesmas Pauh Kambar dan Puskesmas Ulakan lebih dari setengah adalah tidak cacat atau tingkat cacat 0 .

Didapatkan lebih dari setengah responden memiliki pengetahuan yang kurang tentang penyakit kusta.

Didapatkan lebih dari setengah responden memiliki sikap yang baik terhadap penderita kusta.

Adanya hubungan yang bermakna antara pengetahuan dan sikap keluarga dengan tingkat kecacatan penderita kusta.

\section{DAFTAR PUSTAKA}

1. Ricardo S, Guinto MD. Atlas kusta. Sasakawa Memorial Health Foundation, Japan; 2004.

2. Ditjen PPM \& PL Dep. Kes. RI. Buku pedoman nasional pemberantasan penyakit kusta. Jakarta; 2006.

3. WHO. Weekly epidemiological record. Geneva, Switzerland: World Health Organization; 2013.

4. Kementrian Kesehatan RI. Profil kesehatan indonesia tahun 2011. Jakarta; 2012.

5. Dinas Kesehatan Provinsi Sumatra Barat. Data penderita kusta Sesumatera Barat. Padang: Dinas Kesehatan Sumatera Barat; 2011.

6. Dinas Kesehatan Kabupaten Padang Pariaman. Laporan tahunan P2. Padang Pariaman: Dinas Kesehatan Kabupaten Padang Pariaman; 2011.

7. Rahayu DA. Pengaruh psikoedukasi keluarga terhadap dukungan psikososial keluarga pada anggota keluarga dengan penyakit kusta di Kabupaten Pekalongan (tesis). Jakarta: Fakultas IImu Keperawatan Universitas Indonesia; 2011.
8. Notoatmodjo S. Promosi kesehatan dan ilmu perilaku. Jakarta: Rineka Cipta; 2007.

9. Susanto N. Faktor-faktor yang berhubungan dengan tingkat kecacatan penderita kusta (kajian di Kabupaten Sukoharjo) (tesis). Yogyakarta: Sekolah Pasca Sarjana Universitas Gadjah Mada; 2006.

10. Wabula N. Analisis hubungan pengetahuan dan sikap pasien kusta dengan upaya pencegahan kecacatan penyakitnya di rumah sakit $d r$. Tadjuddin Chalid Makassar tahun 2009 (skripsi). Makassar: Fakultas Kedokteran Universitas Hasanuddin; 2010.

11. Fontaine KL. Mental health nursing. New Jersey: Pearson Education Inc; 2003.

12. Potter PA, Perry AG. Fundamental of nursing: concept, process, and practice. Philadelphia: Mosby Years Book Inc; 2005.

13. Donelan K, Hill CA, Hoffman C, Scoles K, Feldman $\mathrm{PH}$, Levine $\mathrm{C}$, et al. Challenged to care: informal caregivers in a changing health system. Health Aff. 2002;21:222-31.

14. Bomar PJ. Promoting health in families: applying family research and theory to nursing practice. Edisi ke-3.. Philadelphia: Library of Congress in Publication Data; 2004.

15. Notoadmojo S. Ilmu kesehatan masyarakat prinsipprinsip dasar. Jakarta: Rineka Cipta; 2005.

16. Mongi R. Gambaran persepsi penderita tentang penyakit kusta dan dukungan keluarga pada penderita kusta di Kota Manado. 2012 (diunduh 28 September 2013). Tersedia dari: URL: HYPERLINK http:/fkm.unsrat.ac.id/wp-content/ uploads/2012/10/RilauniMongi.pdf

17. Harju BL, Wuensch KL, Kuhl EA.Comparison of rural and urban residents' implicit and explicit attitudes related to seeking medical care. J Rural Health. 2006;22:359-63.

18. Antari L. Hubungan tingkat pengetahuan, sikap dan praktik keluarga penderita kusta dalam upaya pencegahan kecacatan dengan kejadian kecacatan kusta di Kabupaten Tegal (undergraduate thesis). Diponegoro University. 2011 (diunduh 26 Februari 2014). 
Tersedia dari: URL: HYPERLINK http://eprints.undip.ac.id/34996/n

19. Permani D. Hubungan pengetahuan, sikap dan tindakan kontak serumah dengan kejadian kusta di Kabupaten Padang Pariaman. 2009 (diunduh 25 Februari 2014). Tersedia dari: URL: HYPERLINK http://repository.unand.ac.id/5617/

20. Notoatmodjo S. Pendidikan dan perilaku kesehatan. Jakarta: Rineka Cipta; 2003.

21. Bakker M, Hatta M, Kwenang A, Klaster PR, Oskam L. Epidemiology and prevention of leprosy: a cohort study In Indonesia; epidemiology of leprosy on five isolated islands in the Flores Sea.
KIT Biomedical Research, Melbergdreef 39. Nethderlands; 2005.

22. Eliningsih D. Faktor-faktor yang berhubungan dengan kecacatatan pada penderita kusta di Kabupaten Tegal. 2010 (diunduh 25 Februari 2014). Tersedia dari: URL: HYPERLINK http://www.fkm.undip.ac.id/data/index.php?action= $\underline{4 \& i d x=3925}$

23. Azwar S. Penyusunan skala psikologi. Yogyakarta: Pustaka Pelajar; 2011.

24. Zulkifli. Penyakit kusta dan masalah yang ditimbulkannya. Medan: Universitas Sumatera Utara Digital Library.2003 